\title{
Synthesis of functionalized diazocines for application as building blocks in photo- and mechanoresponsive materials
}

\author{
Widukind Moormann, Daniel Langbehn and Rainer Herges*
}

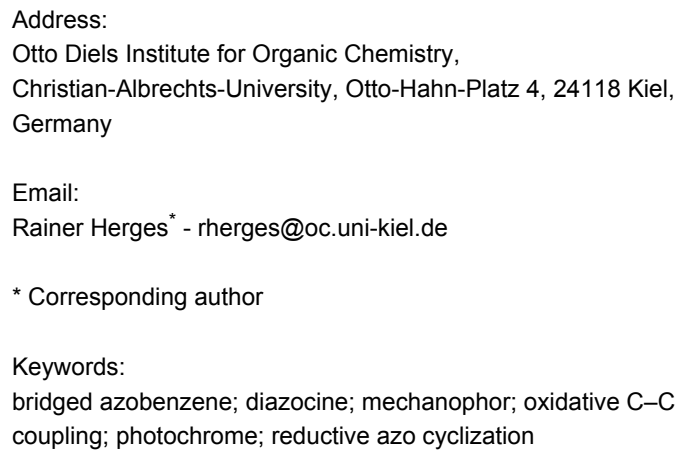

\author{
Beilstein J. Org. Chem. 2019, 15, 727-732. \\ doi:10.3762/bjoc. 15.68 \\ Received: 12 December 2018 \\ Accepted: 09 March 2019 \\ Published: 20 March 2019 \\ Associate Editor: J. A. Murphy \\ (C) 2019 Moormann et al.; licensee Beilstein-Institut. \\ License and terms: see end of document.
}

\begin{abstract}
Seven symmetrically 3,3'-substituted diazocines were synthesized. Functional groups include alcohol, azide, amine and vinyl groups, which are suitable for polymer synthesis. Upon irradiation at 385 and $530 \mathrm{~nm}$ the diazocines perform a reversible, pincertype movement switching the 3,3'-distance between $6.1 \AA$ (cis, stable isomer) and $8.2 \AA$ (trans, metastable isomer). Key reactions in the synthesis are an oxidative $\mathrm{C}-\mathrm{C}$ coupling of 2-nitrotoluenes (75-82\% yield) and a reductive ring closure to form the diazocines (56-60\% yield). The cyclization of the dinitro compound to the azo compound was improved in yield and reproducibility, by over-reduction to the hydrazine and reoxidation to the azo unit. In contrast to 3,3'- and 4,4'-diaminodiazocine, which have been implemented in macromolecules for conformation switching, our compounds exhibit improved photophysical properties (photostationary states, separation of absorption bands in the cis and trans configuration). Hence they are promising candidates as molecular switches in photo and mechanoresponsive macromolecules and other smart materials.
\end{abstract}

\section{Introduction}

The field of photoresponsive materials is of growing interest [1-3]. Several mechanophores such as azobenzene [4-8], diarylethene [9-13] and spiropyrans [14-18] have been investigated as photoswitchable building blocks. Bridged azobenzenes also known as diazocines exhibit excellent photochemical properties but applications are limited and suitably functionalized compounds are rare [19-23]. In contrary to azobenzenes, diazocines $\mathbf{1}$ are stable in their cis configuration. The bent cis isomer is less prone to $\pi-\pi$ stacking which is known to reduce the switching efficiency (Figure 1a) [19,24]. The reverse stability of the cis and trans isomers in azobenzenes and diazocines should allow reciprocal applications in mechanoresponsive materials and in photopharmacology [25]. Another advantage of diazocines over azobenzenes is their switchability in the visible range (400 nm cis $\rightarrow$ trans, $530 \mathrm{~nm}$ trans $\rightarrow$ cis) preventing deterioration of the material or tissue damage by UV light [19]. Well separated absorption bands, high switching efficiency and high quantum yields are further advantages 
a)

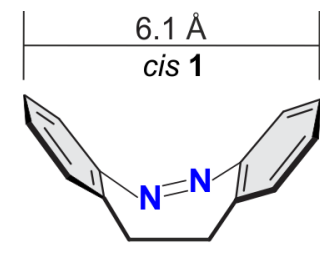

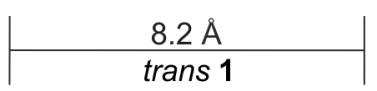
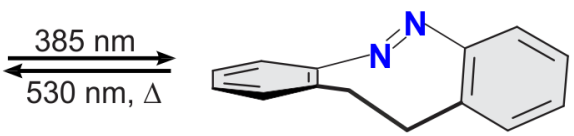

b)
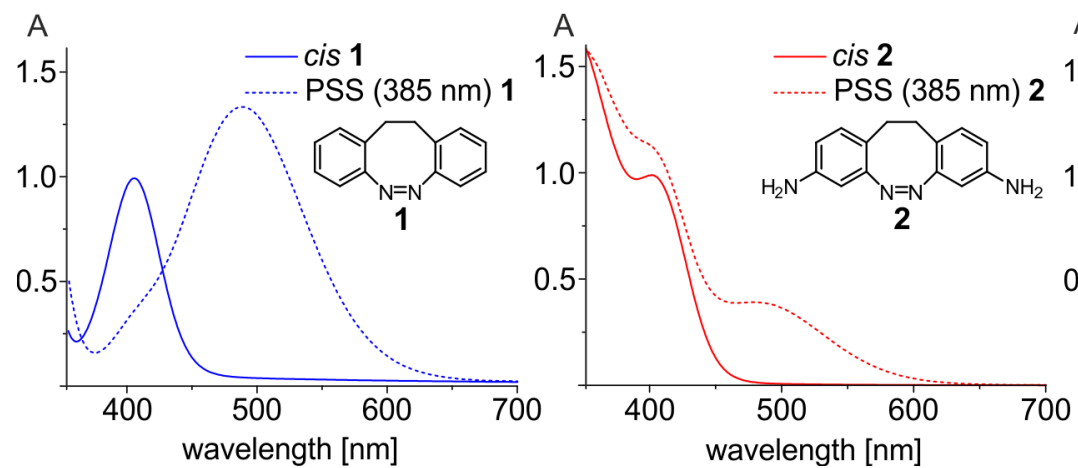

A

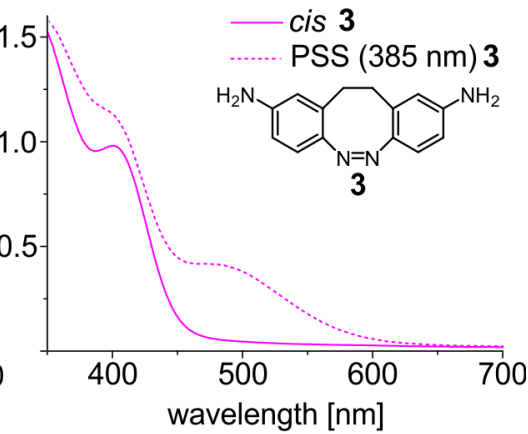

Figure 1: (a) Isomerization of parent diazocine 1. Distances of carbon atoms para to the ethylene bridge were determined at the B3LYP/6-31 $\mathrm{g}^{*}$ level of DFT [23]. (b) UV-vis spectra of parent diazocine 1 (left), 3,3'-diaminodiazocine 2 (center) and 4,4'-diaminodiazocine 3 (right). Continuous lines: $100 \%$ cis and dashed lines: PSS $(385 \mathrm{~nm})$ at $298.15 \mathrm{~K}$ in acetonitrile.

regarding their application as switches in photoresponsive materials $[19,24,26]$. In contrast to spiropyrans which have been frequently used as photoswitches in materials, diazocines are stable over several thousand switching cycles under air [19,24,26,27]. Notwithstanding their excellent properties, to date only 3,3'- and 4,4'- functionalized diazocine $\mathbf{2}$ and $\mathbf{3}$ have been implemented in polymers [19] and proteins [28]. Unfortunately, similar to azobenzenes, aminosubstitution at the phenyl rings reduces switching efficiency [29]. In contrast to the parent system, separation of absorption bands of the cis and trans isomer in $\mathbf{2}$ and $\mathbf{3}$ is poor. Upon irradiation of the corresponding cis-configured compounds at $385 \mathrm{~nm}$ only $30 \%$ of the trans isomer of 3,3'-diazocine $\mathbf{2}$ and $25 \%$ of the 4,4'-diazocine 3 are formed (Figure 1b). Applications of diazocines $\mathbf{2}$ and $\mathbf{3}$ are further hampered by the low yields of their synthesis $[19,20]$

To decouple the electronic influence of the functional groups from the azo switching process and to improve yields of the azo cyclization step, we separated the functional groups from the aromatic system by one or two methylene groups and restricted substitution to the position meta with respect to the azo group (Figure 2) [19,20].

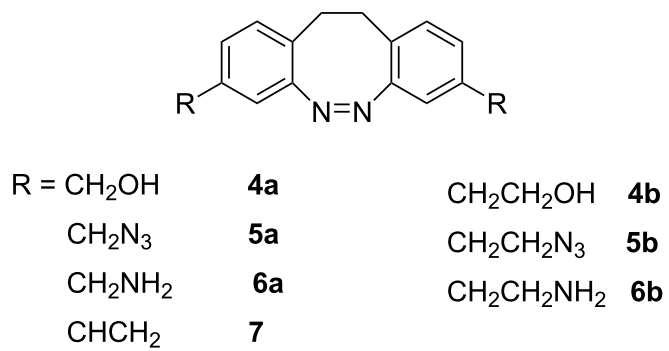

Figure 2: Synthesized target diazocines 4-7 for applications in responsive materials.

\section{Results and Discussion}

The synthesis of the targeted diazocines 4-7 is based on two key reactions, an oxidative $\mathrm{C}-\mathrm{C}$ coupling of nitrotoluenes and the reductive ring closure of the dinitro compounds (Scheme 1). We recently improved the yield of the $\mathrm{C}-\mathrm{C}$ coupling through

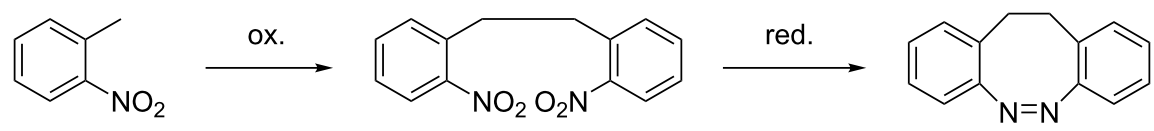


addition of bromine as an oxidizing agent [27]. The reaction times thus are reduced to several minutes as compared to several hours in previous procedures using oxygen and the yields are increased from $65 \%$ to $95 \%$ in the parent system [30].

In a recent work we observed that the reduction of 2,2'-dinitrodibenzyl is difficult to stop at the azo stage because further reduction to the hydrazine is faster than the preceding cyclization reaction [27]. The hydrazine is quite stable towards reduction to the diamine, and can easily be reoxidized to the azo compound using $\mathrm{CuCl}_{2} / \mathrm{O}_{2}$. The yields are higher and more reproducible using the above reduction/reoxidation scheme. Previously applied reducing agents include $\mathrm{Ba}(\mathrm{OH})_{2} / \mathrm{Zn}$ [27], glucose $/ \mathrm{NaOH}$ [20], $\mathrm{Pb} / \mathrm{NEt}_{3} / \mathrm{HCOOH}[22,23]$, or the Baeyer-Mills reaction via $\mathrm{Zn} / \mathrm{NH}_{4} \mathrm{Cl}$ [25]. We chose the $\mathrm{Ba}(\mathrm{OH})_{2} / \mathrm{Zn}$ method because it provided superior yields even at larger scales. The syntheses of the functionalized diazocines 4-7 started with (4-methyl-3-nitrophenyl)methanol (8a) and (4-methyl-3-nitrophenyl)ethanol (8b). In a first step the hydroxy groups in $\mathbf{8 a}$ and $\mathbf{8 b}$ were protected as tert-butyl ethers (Scheme 2) to prevent oxidation in the following oxidative $\mathrm{C}-\mathrm{C}$ coupling [31]. The tert-butyl ether was chosen as the protecting group because it is stable towards the oxidizing conditions of the $\mathrm{C}-\mathrm{C}$ coupling reactions and the reducing conditions of the azo cyclization. Moreover, the tert-butyl group can be conve- niently removed under acidic conditions. As described in [27] potassium butoxide is used as a non-nucleophilic base to remove the $\alpha$-toluene protons of $9 \mathbf{a}$ and $\mathbf{9 b}$. By addition of bromine as an oxidizing agent dimers $10 \mathbf{a}$ and $\mathbf{1 0 b}$ are formed, most probably through radical intermediates. Then the dinitro compounds $10 \mathrm{a}$ and $\mathbf{1 0 b}$ were reduced with $\mathrm{Ba}(\mathrm{OH})_{2} / \mathrm{Zn}$ to the hydrazine intermediates and subsequently oxidized with $\mathrm{CuCl}_{2}$ and air in a two-step reductive azo cyclization in a similar manner as described in [27]. After deprotection with $\mathrm{TiCl}_{4}$ the hydroxy-functionalized diazocines $\mathbf{4 a}$ and $\mathbf{4 b}$ were obtained [32]. The hydroxy groups in $\mathbf{4 a}$ and $\mathbf{4 b}$ were successfully converted into azides using 2-azido-1,3-dimethylimidazolinium hexafluorophosphate (ADMP) and DBU [33]. The synthesis was completed with a Staudinger reaction to obtain the aminofunctionalized diazocines $\mathbf{6 a}$ and $\mathbf{6 b}$ [34]. Additionally, the diazocine $4 \mathbf{b}$ was converted into the divinyldiazocine 7. Towards this end, the hydroxy groups were tosylated, followed by elimination with potassium butoxide $[35,36]$.

The photochemical and photophysical properties of compounds 4-7 were investigated by NMR and UV-vis spectroscopy and the results are listed in Table 1. Photostationary states (PSS) as well as half-lives $\left(t_{1 / 2}\right)$ were determined in acetonitrile at $300 \mathrm{~K}$ and $298.15 \mathrm{~K}$, respectively. The (cis $\rightarrow$ trans) and (trans $\rightarrow$ cis) isomerization were achieved by irradiation into the appropriate

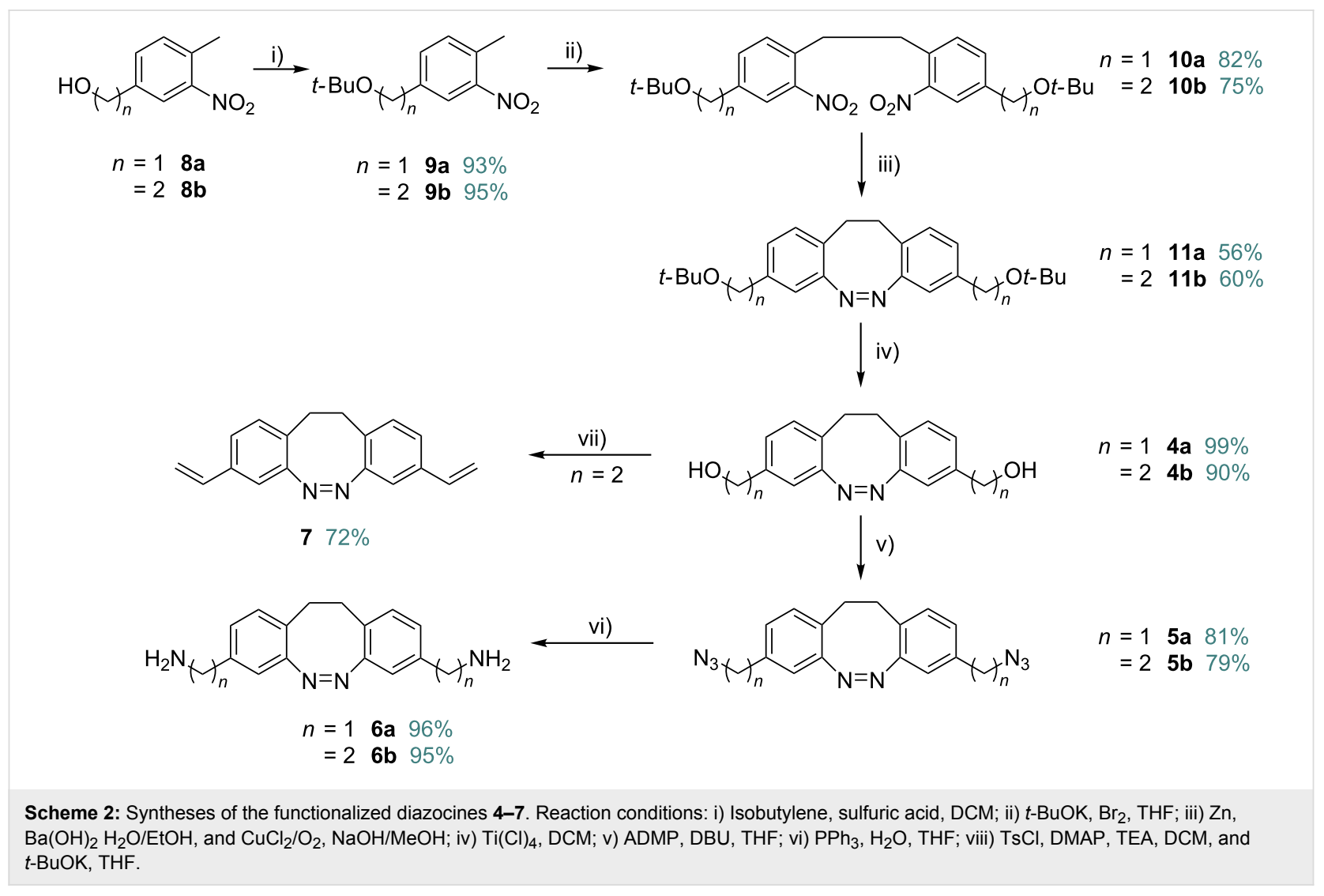


Table 1: Photostationary states ( $300 \mathrm{~K})$, absorption maxima and half-lives ( $298.15 \mathrm{~K})$, determined by ${ }^{1} \mathrm{H}$ NMR and UV-vis spectroscopy in acetonitrile.

\begin{tabular}{|c|c|c|c|c|c|}
\hline molecule & $\begin{array}{c}\text { PSS }(385 \mathrm{~nm}) \\
\text { [\%] trans }\end{array}$ & $\begin{array}{c}\text { PSS }(530 \mathrm{~nm}) \\
{[\%] \text { cis }}\end{array}$ & $\lambda_{\max }(c i s)$ & $\begin{array}{c}\lambda_{\max }(\text { trans }) \\
{[\mathrm{nm}]}\end{array}$ & $\begin{array}{l}t_{1 / 2}(\mathrm{UV})[\mathrm{h}] \\
\text { at } 298.15 \mathrm{~K}\end{array}$ \\
\hline 1 & 87 & $>99$ & 402 & 486 & 15.3 \\
\hline 2 & 30 & $>99$ & 401 & 487 & 24.8 \\
\hline 3 & 25 & $>99$ & 400 & 475 & 20 \\
\hline $4 a$ & 83 & $>99$ & 404 & 485 & 11.4 \\
\hline $4 b$ & 81 & $>99$ & 405 & 487 & 16.7 \\
\hline $5 a$ & 85 & $>99$ & 402 & 484 & 11.2 \\
\hline $5 b$ & 82 & $>99$ & 405 & 489 & 14.0 \\
\hline $6 a$ & 81 & $>99$ & 405 & 488 & 14.7 \\
\hline $6 b$ & 78 & $>99$ & 400 & 485 & 10.1 \\
\hline 7 & 74 & $>99$ & 403 & 484 & 13.1 \\
\hline $11 a$ & 82 & $>99$ & 403 & 487 & 10.2 \\
\hline $11 b$ & 81 & $>99$ & 405 & 488 & 15.9 \\
\hline
\end{tabular}

$\mathrm{n}-\pi *$ bands at 385 and $530 \mathrm{~nm}$. As a result of electronic decoupling the absorption bands are well separated and the photostationary states of diazocines 4-7 are considerably improved compared to 3,3'- (2) and 4,4'-diaminodiazocine 3 (Figure 3). The (cis $\rightarrow$ trans $)$ isomerization of diazocines 4-7 was achieved after $2 \mathrm{~min}$ of irradiation at $385 \mathrm{~nm}$ in yields of $74-85 \%$. All trans-diazocines were converted quantitatively to the cis-configuration either by thermal relaxation or by irradiation at $530 \mathrm{~nm}$. In general, the (trans $\rightarrow$ cis) isomerization can be accomplished with wavelengths between 520 and $620 \mathrm{~nm}$. The half-lives $\left(t_{1 / 2}\right)$ for the thermal relaxation (trans $\rightarrow$ cis) at 298.15 K of diazocines 4-7 in acetonitrile are between $10.2-16.7 \mathrm{~h}$ and thus are in the same order of magnitude as the parent system 1 (15.3 h). In comparison, the 3,3'-diaminodiazocine 2 has a much longer half-life $\left(t_{1 / 2}\right)$ of $24.5 \mathrm{~h}$. The electronic decoupling of substituents in diazocines 4-7 has proven to retain the excellent photochemical properties in regard to PSS and half-life $\left(t_{1 / 2}\right)$ of the parent system 1.

\section{Conclusion}

Seven symmetrically substituted diazocines 4-7 were synthesized and characterized. Oxidative $\mathrm{C}-\mathrm{C}$ coupling and reductive azo condensation proved to be reliable key steps in the synthesis of these substituted diazocines. The photophysical properties of compounds 4-7 were investigated by NMR and UV-vis experiments. The previously investigated 3,3'-diaminodiazocine 2 and 4,4'-diaminodiazocine 3 exhibited poor photostationary states (PSS (385 nm): $25-30 \%$ trans). The electronic decoupling of the azobenzene unit and the oxygen and nitrogen containing functional groups $\left(\mathrm{OH}, \mathrm{OR}, \mathrm{N}_{3}, \mathrm{NH}_{2}\right)$ was achieved by insertion of one or two $\mathrm{CH}_{2}$ groups. Thereby, the switching efficiencies were increased by about a factor of two (PSS

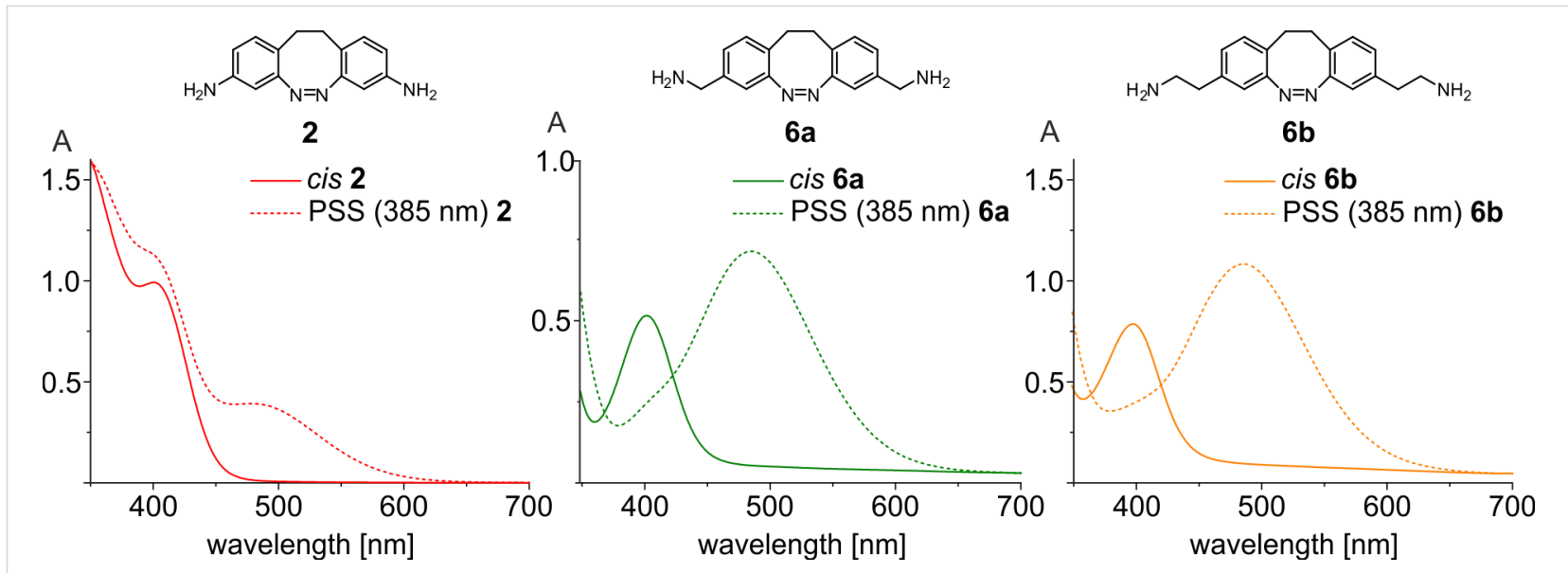

Figure 3: UV-vis spectra of 3,3'-diaminodiazocine 2 (left), 3,3'-di(aminomethyl)diazocine 6a (center), and 3,3'-di(aminoethyl)diazocine 6b (right). Continuous lines: $100 \%$ cis and dashed lines: PSS $(385 \mathrm{~nm})$ at $298.15 \mathrm{~K}$ in acetonitrile. 
(385 $\mathrm{nm}$ ): $74-85 \%$ trans), and thus are close to the parent system 1 (87\%). Moreover, the yields of the two synthetic key steps, the oxidative $\mathrm{C}-\mathrm{C}$ coupling and the azo cyclization have been improved. Diazocines $4 \mathbf{- 7}$ are easily accessible and valuable building blocks for the synthesis of photo- and mechanoresponsive polymers such as polyurethanes, polyesters, polyamides, polyureas and polyolefines.

\section{Supporting Information}

\section{Supporting Information File 1}

Analytical equipment, experimental procedures, NMR and UV-vis spectra.

[https://www.beilstein-journals.org/bjoc/content/ supplementary/1860-5397-15-68-S1.pdf]

\section{Acknowledgements}

The authors gratefully acknowledge financial support by the Deutsche Forschungsgesellschaft (DFG) within the Sonderforschungsbereich 677, "Function by Switching".

\section{ORCID ${ }^{\circledR}$ iDs}

Rainer Herges - https://orcid.org/0000-0002-6396-6991

\section{References}

1. Ikeda, T.; Mamiya, J.-i.; Yu, Y. Angew. Chem., Int. Ed. 2007, 46, 506-528. doi:10.1002/anie.200602372

2. Davis, D. A.; Hamilton, A.; Yang, J.; Cremar, L. D.; Van Gough, D.; Potisek, S. L.; Ong, M. T.; Braun, P. V.; Martínez, T. J.; White, S. R.; Moore, J. S.; Sottos, N. R. Nature 2009, 459, 68-72. doi:10.1038/nature07970

3. Potisek, S. L.; Davis, D. A.; Sottos, N. R.; White, S. R.; Moore, J. S. J. Am. Chem. Soc. 2007, 129, 13808-13809. doi:10.1021/ja076189x

4. Kim, S.-J.; Reneker, D. H. Polym. Bull. 1993, 31, 367-374. doi:10.1007/bf00692965

5. Hosono, N.; Kajitani, T.; Fukushima, T.; Ito, K.; Sasaki, S.; Takata, M.; Aida, T. Science 2010, 330, 808-811. doi:10.1126/science.1195302

6. Kim, C. B.; Wistrom, J. C.; Ha, H.; Zhou, S. X.; Katsumata, R.; Jones, A. R.; Janes, D. W.; Miller, K. M.; Ellison, C. J. Macromolecules 2016, 49, 7069-7076. doi:10.1021/acs.macromol.6b01848

7. Yu, Y.; Nakano, M.; Ikeda, T. Nature 2003, 425, 145. doi:10.1038/425145a

8. Bandara, H. M. D.; Burdette, S. C. Chem. Soc. Rev. 2012, 41, 1809-1825. doi:10.1039/c1cs15179g

9. Luo, Q.; Cheng, H.; Tian, H. Polym. Chem. 2011, 2, 2435-2443. doi:10.1039/c1py00167a

10. Ryo, S.; Ishibashi, Y.; Murakami, M.; Miyasaka, H.; Kobatake, S.; Irie, M. J. Phys. Org. Chem. 2007, 20, 953-959. doi:10.1002/poc.1190

11. Corredor, C. C.; Huang, Z.-L.; Belfield, K. D.; Morales, A. R.; Bondar, M. V. Chem. Mater. 2007, 19, 5165-5173. doi:10.1021/cm071336b
12. Stellacci, F.; Bertarelli, C.; Toscano, F.; Gallazzi, M. C.; Zotti, G.; Zerbi, G. Adv. Mater. (Weinheim, Ger.) 1999, 11, 292-295. doi:10.1002/(sici)1521-4095(199903)11:4<292::aid-adma292>3.0.co;2$\mathrm{v}$

13. Pu, S.-Z.; Sun, Q.; Fan, C.-B.; Wang, R.-J.; Liu, G. J. Mater. Chem. C 2016, 4, 3075-3093. doi:10.1039/c6tc00110f

14. Gossweiler, G. R.; Hewage, G. B.; Soriano, G.; Wang, Q.; Welshofer, G. W.; Zhao, X.; Craig, S. L. ACS Macro Lett. 2014, 3 , 216-219. doi:10.1021/mz500031q

15. Celestine, A.-D. N.; Beiermann, B. A.; May, P. A.; Moore, J. S.; Sottos, N. R.; White, S. R. Polymer 2014, 55, 4164-4171. doi:10.1016/j.polymer.2014.06.019

16. Lee, C. K.; Beiermann, B. A.; Silberstein, M. N.; Wang, J.; Moore, J. S.; Sottos, N. R.; Braun, P. V. Macromolecules 2013, 46, 3746-3752. doi:10.1021/ma4005428

17. Beiermann, B. A.; Davis, D. A.; Kramer, S. L. B.; Moore, J. S.; Sottos, N. R.; White, S. R. J. Mater. Chem. 2011, 21, 8443. doi:10.1039/c0jm03967e

18. Klajn, R. Chem. Soc. Rev. 2014, 43, 148-184. doi:10.1039/c3cs60181a

19. Li, S.; Han, G.; Zhang, W. Macromolecules 2018, 51, 4290-4297. doi:10.1021/acs.macromol.8b00687

20. Sell, H.; Näther, C.; Herges, R. Beilstein J. Org. Chem. 2013, 9, 1-7. doi:10.3762/bjoc.9.1

21. Tellkamp, T.; Shen, J.; Okamoto, Y.; Herges, R. Eur. J. Org. Chem. 2014, 5456-5461. doi:10.1002/ejoc.201402541

22. Joshi, D. K.; Mitchell, M. J.; Bruce, D.; Lough, A. J.; Yan, H. Tetrahedron 2012, 68, 8670-8676. doi:10.1016/j.tet.2012.06.007

23. Hammerich, M.; Schütt, C.; Stähler, C.; Lentes, P.; Röhricht, F.; Höppner, R.; Herges, R. J. Am. Chem. Soc. 2016, 138, 13111-13114. doi:10.1021/jacs.6b05846

24. Siewertsen, R.; Neumann, H.; Buchheim-Stehn, B.; Herges, R.; Näther, C.; Renth, F.; Temps, F. J. Am. Chem. Soc. 2009, 131, 15594-15595. doi:10.1021/ja906547d

25. Schehr, M.; Hugenbusch, D.; Moje, T.; Näther, C.; Herges, R. Beilstein J. Org. Chem. 2018, 14, 2799-2804. doi:10.3762/bjoc.14.257

26. Siewertsen, R.; Schönborn, J. B.; Hartke, B.; Renth, F.; Temps, F. Phys. Chem. Chem. Phys. 2011, 13, 1054-1063. doi:10.1039/c0cp01148g

27. Moormann, W.; Langbehn, D.; Herges, R. Synthesis 2017, 49, 3471-3475. doi:10.1055/s-0036-1590685

28. Samanta, S.; Qin, C.; Lough, A. J.; Woolley, G. A. Angew. Chem. 2012, 124, 6558-6561. doi:10.1002/ange.201202383

29. Rau, H. Azo Compounds. Photochromism: Molecules and Systems, 1st ed.; Elsevier: Amsterdam, The Netherlands, 2003; pp 165-192. doi:10.1016/b978-044451322-9/50008-7

30. Chaudhuri, N. K.; Ball, T. J. J. Labelled Compd. Radiopharm. 1981, 18, 1189-1196. doi:10.1002/jlcr.2580180814

31. Beyerman, H. C.; Bontekoe, J. S. Proc. Chem. Soc., London 1961, 249.

32. Schlessinger, R. H.; Nugent, R. A. J. Am. Chem. Soc. 1982, 104, 1116-1118. doi:10.1021/ja00368a044

33. Kitamura, M.; Koga, T.; Yano, M.; Okauchi, T. Synlett 2012, 23, 1335-1338. doi:10.1055/s-0031-1290958

34. Meguro, T.; Yoshida, S.; Hosoya, T. Chem. Lett. 2017, 46, 473-476. doi:10.1246/cl.161159

35. Stokes, B. J.; Opra, S. M.; Sigman, M. S. J. Am. Chem. Soc. 2012, 134, 11408-11411. doi:10.1021/ja305403s 
36. Thiraporn, A.; Rukachaisirikul, V.; lawsipo, P.; Somwang, T.; Tadpetch, K. Eur. J. Org. Chem. 2017, 7133-7147.

doi:10.1002/ejoc.201701272

\section{License and Terms}

This is an Open Access article under the terms of the Creative Commons Attribution License

(http://creativecommons.org/licenses/by/4.0). Please note that the reuse, redistribution and reproduction in particular requires that the authors and source are credited.

The license is subject to the Beilstein Journal of Organic Chemistry terms and conditions:

(https://www.beilstein-journals.org/bjoc)

The definitive version of this article is the electronic one which can be found at:

doi:10.3762/bjoc. 15.68 